Article

\title{
Walkability, Land Use and Physical Activity
}

\author{
Yehua Dennis Wei ${ }^{1, *}$, Weiye Xiao ${ }^{1}$, Ming Wen ${ }^{2}$ and Ran Wei ${ }^{1}$ \\ Received: 4 October 2015; Accepted: 6 January 2016; Published: 11 January 2016 \\ Academic Editor: Marc A. Rosen \\ 1 Department of Geography, University of Utah, Salt Lake City, UT 84112, USA; weiye.xiao@utah.edu (W.X.); \\ ran.wei@utah.edu (R.W.) \\ 2 Department of Sociology, University of Utah, Salt Lake City, UT 84112, USA; ming.wen@soc.utah.edu \\ * Correspondence: wei@geog.utah.edu; Tel.: +86-801-585-0545; Fax: +86-801-585-8218
}

\begin{abstract}
Physical activity (PA) promotes healthy life and contributes to sustainable development. In this paper, we rely on the Utah Household Travel Survey data and analyze the determinants of PA in terms of neighborhood land use, accessibility to transportation, and socio-demographic status in Salt Lake County, Utah, United States using four-component walkability indices at various geographic scales. We find that PA is associated with neighborhood land use and social demographic status, including the compact design of the neighborhood. The results also indicate that land use mix is insignificant, and that current neighborhood design only supports people's 20-min walk. The spatial lag model reveals significant spatial autocorrelation of PA but the barely improved $\mathrm{R}^{2}$ validates the dominant effect of neighborhood land use and social demographic status on people's walking behavior.
\end{abstract}

Keywords: walkability; land use; physical activity; spatial regression; Salt Lake County

\section{Introduction}

The United States is troubled by a high obesity rate, although the rate at which it is increasing appears to have slowed [1]. The same trend is evident in Salt Lake County in which approximately $25.4 \%$ of adults are obese, and childhood obesity rates are also on the rise [2]. High obesity prevalence has clearly become a legitimate public health concern, motivating researchers to examine the determinants of obesity problems. Given that physical inactivity is widely considered as a major risk factor for overweight and obesity [3,4], increasing physical activity (PA) would help to promote citizens' health and contribute to sustainable development.

A large body of literature has emerged to address the effects of social environment and urban form on PA. Evidence shows that physical inactivity results from the synthesis of urban amenity, socio-demographic status, personal preference, and genetic factors [5]. Density, diversity and accessibility are driving factors of PA, and residents living in neighborhoods characterized by higher residential density and land-use diversity tend to walk more [6]. Mixed land use, higher network connectivity and denser residential space can help to improve neighborhood walkability [7]. PA is also associated with neighborhood social and environmental factors, such as socio-demographic status, transportation, land-use pattern, and neighborhood design [8-13].

This study first maps the spatial distribution of walking behavior and land-use factors and then explores the spatial autocorrelation and clustering of walking behavior. Second, we test the validity of four land use measures to predict walking behavior at different geographical scales. Last, we examine the relationships between walking behavior and neighborhood social and physical characteristics, including transportation and socio-demographic status. 


\section{Literature Review}

\subsection{Physical Activity: Benefits and Measurements}

PA is defined as any bodily movement produced by skeletal muscles that results in energy expenditure [14]. Regular PA is regarded as an important component of a healthy lifestyle [15]. The benefits of PA are well documented, and it is widely recognized that increasing PA can help to prevent excessive weight gain [12,16-19], improve disease control [15,20,21], reduce the symptoms of depression [22], and more generally, enhance health. The American College of Sports Medicine and the Centers for Disease Control and Prevention recommended 30-min of moderate or vigorous PA (e.g., walking and jogging) per day for five days a week for 18-65 year-old-healthy adults [23].

Developing a reliable tool to quantify PA is a priority. A wide range of methods in the form of subjective or objective tools are available to capture PA. The most commonly used tools are the subjective tools like surveys and questionnaires. Baecke et al. [24] classify habitual PA into 29 items, which concern occupation, movement, and PA during leisure time, including sports and sleeping habits. By evaluating over 10 questionnaires about PA, Jacobs et al. [25] call for a more comprehensive questionnaire about different kinds of PA. The "last 7 day recall", which includes questions about people's PA participation in the last seven days, proves to be suitable for PA research [26]. There are many resources for survey-based and self-reported measurement of PA, some of which are published and accessible online [27]. Compared with subjective measures, objective measures are more precise and reliable [28]. However, the high cost of the techniques entailed in collecting objective PA data impedes its wide application. Accelerometer is one of the widely used objective tools in PA research and performs well [29-32]. Using both objective and subjective PA measurement tools is encouraged in future PA work [31].

\subsection{Determinants of $P A$}

PA participation in the US is not adequate, and one in three adults and four in five adolescents do not meet levels of PA recommended by public health guidelines [14,32-34]. The etiology of individuals' participation in PA, including socio-demographic status and individual characteristics, has drawn much attention. Age is one of the most examined demographic factors. Teenagers' participation in PA declines drastically as they grow up. PA participation tends to be stable in young and middle-aged adulthood, then increases a little after middle-age adulthood and declines in old age [14,35-37]. Gender is another important PA correlate, although the observed pattern has not been always consistent [34,38-41]. PA is also linked to family structure at least among children [42]. Finally, PA prevalence is higher among Caucasians than African-American and Hispanics [4,43].

The relationship between urban form and travel behavior is a key concern of urban planning [44]. Among various urban forms, mixed land use and public transit are found to facilitate residents' travel-based PA [45]. The sprawl index, a linear combination of 22 land-use variables, seems to be associated with PA, as people living in sprawling metropolitan areas tend to walk less and weigh more [46]. High levels of PA are detected in the neighborhoods with highly mixed land use, high density and great accessibility to work opportunity [47-49]. Street design features such as street connectivity, street safety, sidewalk and crosswalk in the neighborhoods are also examined with results showing that people walk more in a well-connected and safe street [47-49]. Furthermore, neighborhood amenities like access to parks are also linked to PA, with park amenity characteristics appearing to be better determinants of PA than park accessibility [50,51].

\subsection{Walkability and Land-Use}

Walking is recommended as one of the best forms of moderate-vigorous physical activities. Compared to vigorous PA, walking is suitable for people at all ages $[17,23]$. In order to promote walkability, the " $5 \mathrm{D}$ " theory, which includes population density, pedestrian-friendly design, diversity of destinations, destination accessibility, and distance to transit, is proposed as a measure of urban 
form, and walkability increases with the increase in the values of the " $5 \mathrm{D}$ " variables $[9,47,52-54]$. The original walkability index is proposed to include three variables: street connectivity, net residential density, and land use mix, which respectively describes the pedestrian-friendly design, population density and diversity of neighborhood land use [11]. The retail floor area ratio is then added to achieve a more favorable result [12]. This four-component walkability index is used in many studies concerning walkability [55-61]. However, the application of the four-component walkability index is still limited. A context-specific walkability index is proposed by Mayne et al. [58] and Christian et al. [10]. Mayne et al. [58] test the validity of the context-specific walkability index and find that the context-specific walkability index can maintain about $90 \%$ of the full walkability index. Likewise, a three-component walkability index developed based on a PA study in Sweden stresses that future policies concerning the built environment should be based on context-specific factors [62].

Among these four components of walkability index, land-use mix is the most emphasized. For instance, by testing the effect of multi-category land-use mix on obesity, Brown et al. [7] argue that walkable land-use relates to healthy weight. As a component of walkability index, varying combination of land-use mix is also suggested to affect the strength of the relationship with different types of walking [10]. Geographical scale is also a key element in calculating land-use mix $[63,64]$. However, land-use mix is not always a significant indicator of walkability [10], and the performance of land-use mix depends on the types of trips and study areas [10,58].

In summary, two limitations in the current literature are noteworthy. First, little work has been carried out to take spatial autocorrelation into consideration and to employ spatial regression models. Both these methods are important because walking is a spatial behavior with spatial clustering and variation. Second, the effect of context-specific walkability indices constructed on various geographical scales is less studied and remains largely unknown.

\section{Data and Methodology}

\subsection{Study Area and Data Source}

The validity of land use and walkability indices is evaluated in the Salt Lake County, which covers over $2000 \mathrm{~km}^{2}$ and has a population of about 1 million in 2010. This research primarily relies on the Utah Household Travel Survey (UHS), which was a travel diary-based survey conducted in 2012 by multiple state government agencies and organizations, including Wasatch Front Regional Council, Utah Department of Transportation, and Utah Transit Authorities. This survey took three days to record 101,404 biking, driving and walking trips taken by 27,064 individuals living in 9155 households across the State of Utah. About 2800 households in Salt Lake County participated in this survey [65]. However, people in some households did not report their walking trips or their walking behavior. After checking thes data, 158 households in Salt Lake County with complete information were selected as samples in this research. The spatial distribution of these 158 households is presented in Figure 1. The spatial data, including locations of public facilities, road network, and bus and light rail stations, come from the Utah Automatic Geographic Reference Center. Additionally, the land use data at the parcel level is from Salt Lake County 2012 tax assessor's Computer assisted mass appraised (CAMA) data. 


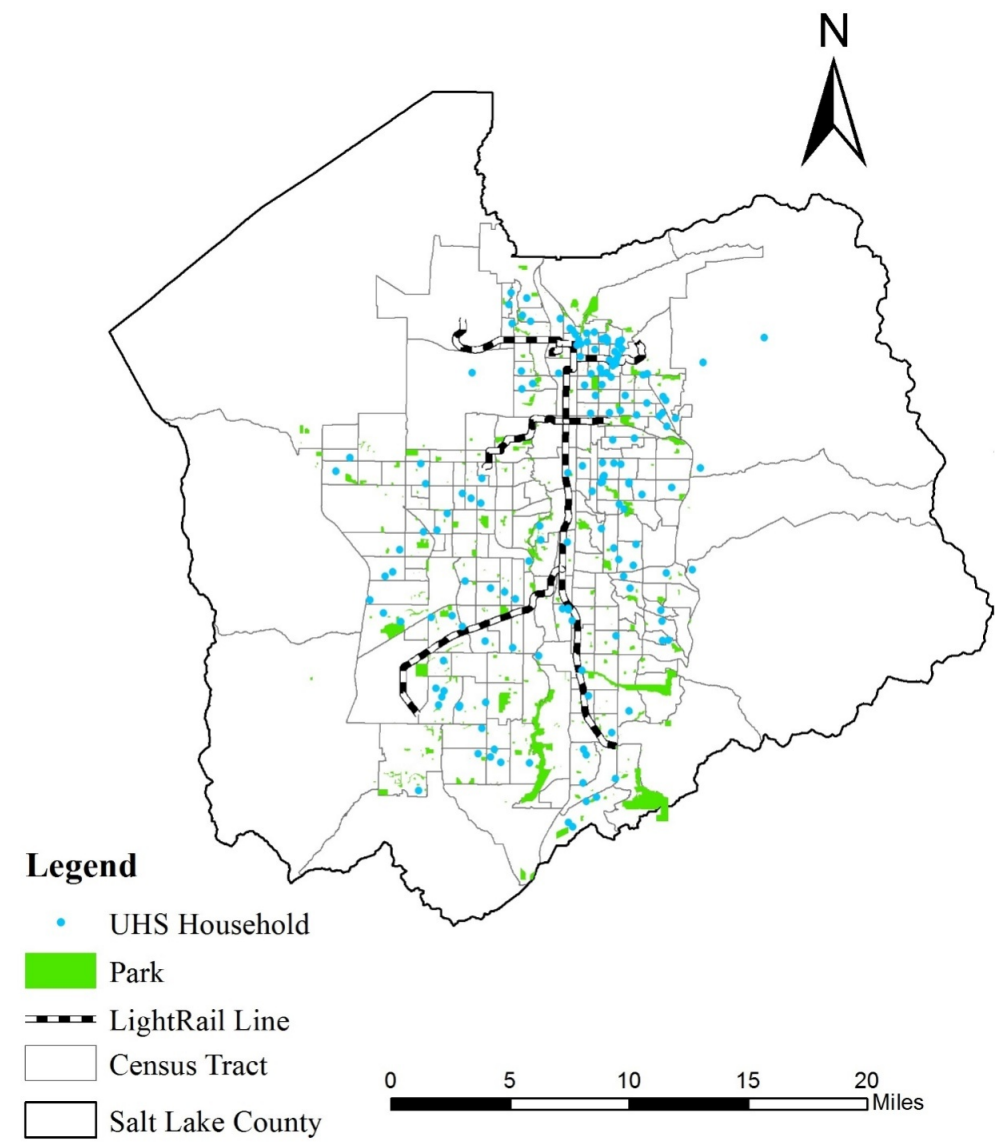

Figure 1. Study area.

\subsection{Measures}

According to previous research on PA $[8,10,11]$, the average of an individual's walking minutes is a proper dependent variable to measure walking behavior. Since it is a trip-level data and the neighborhood environment is measured at household level, the data are aggregated into household level.

With the records of people's walking trips, the frequency of walking every week and the household size, the average value of people's walking minutes for each household can be estimated and used as the dependent variable. Due to the fact that the dependent variable is skewed, the natural $\log$ transformation is used to achieve a continuous dependent variable with approximate normal distribution. We consider the independent variables as the accessibility to transportation, amenities, socio-demographic conditions (household level), land use, and walkability index (Table 1). Transportation, amenities, land use and walkability index are calculated using ArcGIS, the most popular commercial GIS software, and Python, an open-source programming language.

Table 1. Definition of variables.

\begin{tabular}{|c|c|}
\hline Dependent Variables & Description \\
\hline$P A$ & Ln (Average time of people's walking trips) \\
\hline Predictor Variables & Description \\
\hline Accessibility (AS) & $\begin{array}{c}\text { Ln (Distance to closest bus station) } \\
\text { Ln (Distance to closest light rail station) }\end{array}$ \\
\hline Amenity $(A)$ & $\begin{array}{c}\text { Ln (Distance to closest park) } \\
\text { Ln (Distance to closest worship) }\end{array}$ \\
\hline
\end{tabular}


Table 1. Cont.

\begin{tabular}{cc}
\hline Dependent Variables & Description \\
\hline \multirow{3}{*}{ Socio-demographic Conditions (SC) } & Average Age \\
\cline { 2 - 2 } & Average Education level \\
Land use and Walkability index & Percentes per person \\
& Average Household Income (4-caterogry data) \\
\hline & Dwelling Density \\
& Street Connectivity \\
Land-Use Mix \\
\end{tabular}

\subsection{Statistical Methods}

Ordinary least squares (OLS) modeling is performed to examine the relationship between average time of walking trips and walkability index, transportation, amenities, and socio-demographic status. However, since previous studies have shown that people's walking minutes largely depend on neighborhood environment [11,47], walking minutes are likely to be spatially autocorrelated. Spatial autocorrelation test is also conducted, which confirm the existence of such spatial autocorrelation. The Moran's I is 0.26 with statistical significance. Given that ignoring the spatial autocorrelation could cause biased and inconsistent estimates for the regression coefficients [66], spatial lag model is employed to incorporate the spatial autocorrelation of walking time by introducing a spatially lagged dependent variable in the regression equation as follows:

$$
y=\rho \times W \times y+\beta \times x+\varepsilon
$$

$y$ is the walking time to be regressed, $\rho$ is the spatial autoregressive coefficient, and $W$ is the spatial weight matrix defining neighbors for each location. In this case, the point based method, Delaunay triangulation is employed to define the spatial weight matrix W. According to the method, the circumcircle of any triangle contains no point in its interior [67]. If a leg of a Delaunay triangle connects observation $i$ and $j$, it sets the elements in the unweighted spatial weight matrix $D(i, j)=1[68]$. This will naturally result in a symmetric matrix. With a row-standardized spatial weight matrix, $W \times y$ is the average of the neighbors' walk minutes, which is usually referred to a spatially lagged dependent variable. $x$ and $\beta$ are the independent variables and their corresponding coefficients. $\rho$ is the coefficient for the spatially lagged dependent variable. $\varepsilon$ is a vector of the error term. In this model, the spatial autocorrelation is measured as an independent variable in the regression model and the spatial regression model can get better model performance and predictive accuracy [69].

\section{Walkability Index and PA}

Walkability is initially operationalized as a composite of four environmental attributes within the neighborhood area, which is defined by the road network buffer with specified bandwidth:

Dwelling density: Residential parcels within the buffer area are selected and then the total area of the selected parcels and the total number of dwelling units are summarized. Dwelling density is finally calculated by dividing the number of dwelling units by the total area of residential parcels within the neighborhood. The high dwelling density can not only improve the accessibility of complementary activities, but also compress the living space [56].

Street connectivity: Connectivity is measured by the number of intersections per square kilometer within the network buffer. Only the intersections with three or more unique intersecting streets are included in the street connectivity calculation.

Land-use mix: Land-use mix is used to evaluate the evenness in the distribution of land use. If the land use is evenly distributed in the network buffer, the value of land use mix would be 1 . If there is 
only one type of land use in the network buffer, the value would be 0 . The method to calculate land use mix and the relationship between land use mix and walkability is well discussed by Christian et al. [10]. The land use mix described in this paper is calculated with four land use types: residential, commercial, industrial, and recreational.

Retail floor area ratio: the parcels in commercial use are used to calculate the retail floor area ratio. Salt Lake County 2012 tax assessor's computer-assisted mass appraisal (CAMA) database provides the ground floor area for each parcel. Retail floor area ratio is the total ground floor area divided by the total area in household network buffer. High retail floor area ratio means more optional destinations for shopping and more local employed opportunities within the walking distance [56]. The parking space would be compressed as well and walking is more encouraged.

While selecting a proper geographic scale is discussed in the previous studies, little thought is given regarding how or why these geographic scales should be selected to define neighborhood areas [70]. The importance of geographical scale and multilevel approaches are also emphasized in PA research [6,71,72]. Yamada et al. [63] have employed three different geographical scales, 1-km network buffer, block group, and census track, to demonstrate that different geographical scales could lead to different walkability measures. Moudon et al. have employed four scales of neighborhood to identify walkable neighborhoods [73]. Schlossberg and Brown have also studied the relationship between walkability indicators and transit-oriented development at two geographical scales ( 0.25 mile and 0.5 mile) [74]. Since this research aims to create a context-specific walkability index, multi-scale tests on the performance of these four components are conducted to explain PA. A variety of bandwidths is used to buffer the road network to define neighborhood area, including $400 \mathrm{~m}$ (5-min walk), $600 \mathrm{~m}$, $800 \mathrm{~m}$ (10-min walk), $1000 \mathrm{~m}, 1200 \mathrm{~m}$ (15-min walk), $1500 \mathrm{~m}, 1600 \mathrm{~m}$ (20-min walk), and $1700 \mathrm{~m}$. The OLS model is used to examine the relationship between walkability index and walking minutes with different geographical scales. The results are shown in Figures 2 and 3.

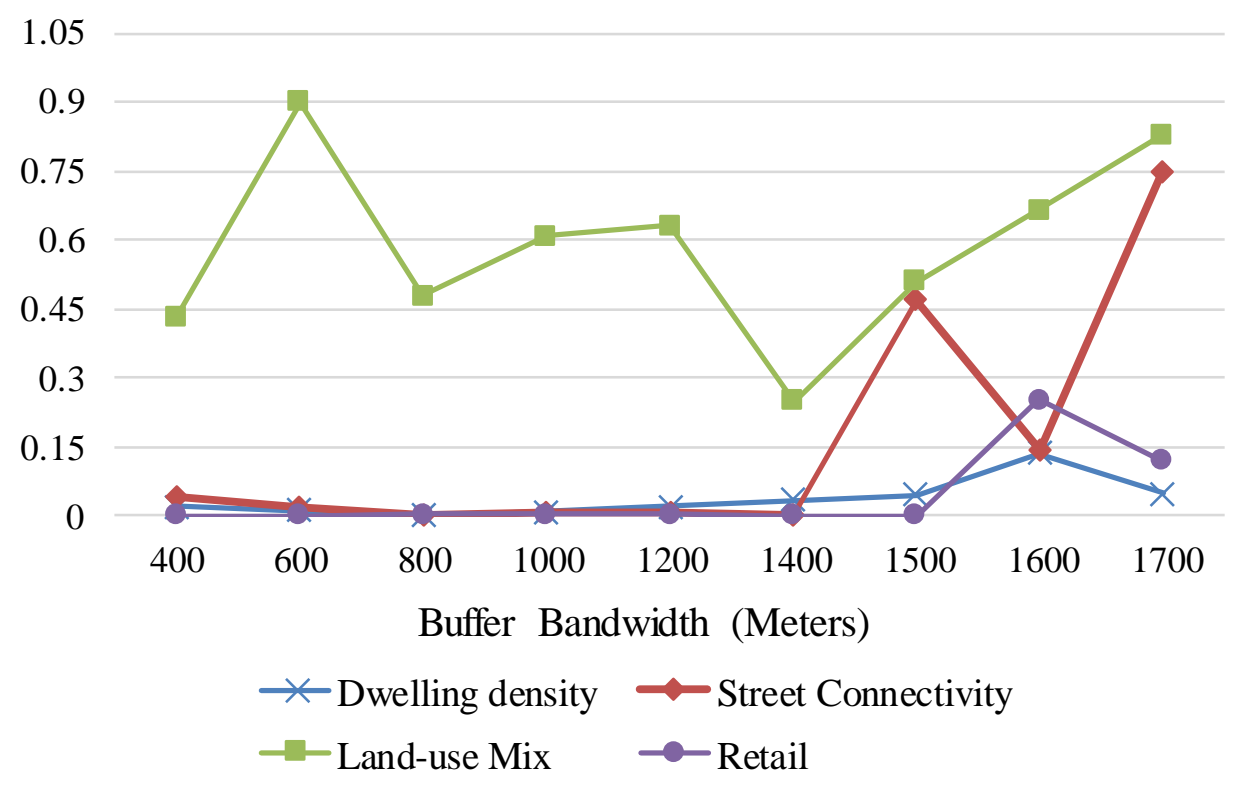

Figure 2. The result of multi-scale test ( $p$-value). 


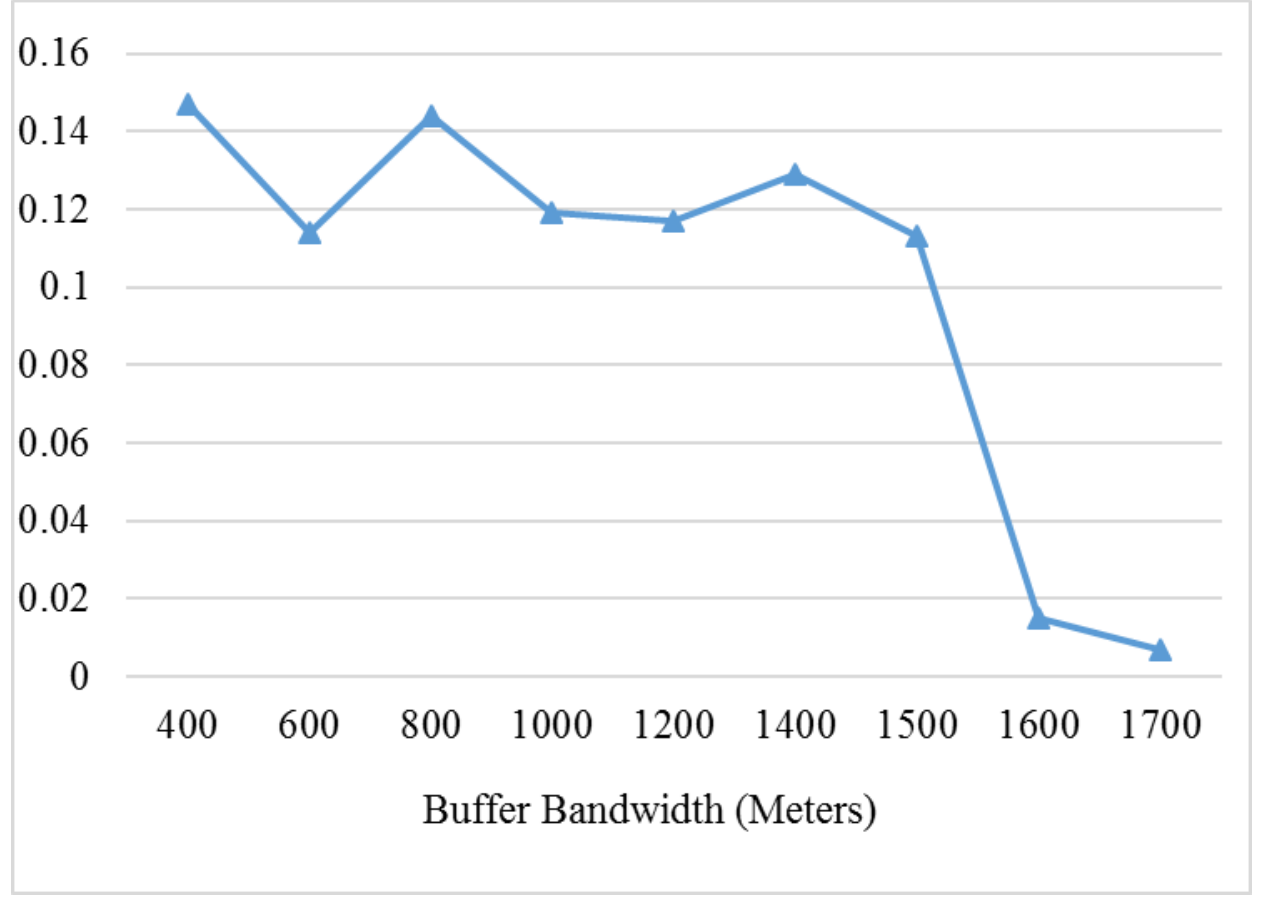

Figure 3. The result of multi-scale test $\left(R^{2}\right)$.

Figure 2 shows the significance of each component. The significance of dwelling density, street connectivity and retail floor area ratio decrease dramatically when the bandwidth of the network buffer reaches about $1600 \mathrm{~m}$. The $\mathrm{R}^{2}$ also experiences a rapid decline around $1600 \mathrm{~m}$, implying that the neighborhood environments, including street connectivity, the commercial land use, and population density, do not affect people's walking trips beyond $1600 \mathrm{~m}$. In other words, the neighborhood environments only affect walk trips within 20-min walking distance in Salt Lake County, and longer trips usually depend on some other factors, such as self-selection. In fact, according to Root's research on geographic scale, in many U.S. urban areas, people routinely travel 5 to 10 miles to carry out many daily activities, such as shopping, taking children to school, or exercising [75]. According to the trip records, the average walking time is about half an hour for each person per day. Comparatively, Salt Lake County is now at a low walkability level and the future development of neighborhood environment is promising to improve walkability.

Another interesting point here is that the land use mix is not significant at any geographical level. Figure 4 shows the spatial clusters of physical activities in Salt Lake County using the local indicator of spatial autocorrelation (LISA). The spatial clusters of land use mix are displayed in Figure 5. Clearly, the clusters of high physical activities are not consistent with those of large land use mix, suggesting that land use mix is not a good indicator of PA or the relationship between land use mix and PA is not linear. Research in Salt Lake County and Australia reveal that the even mixture of land use does not necessarily lead to better walkability. The performance of land use mix is largely affected by the land use category, the type of walking, and the study area $[8,10]$. 


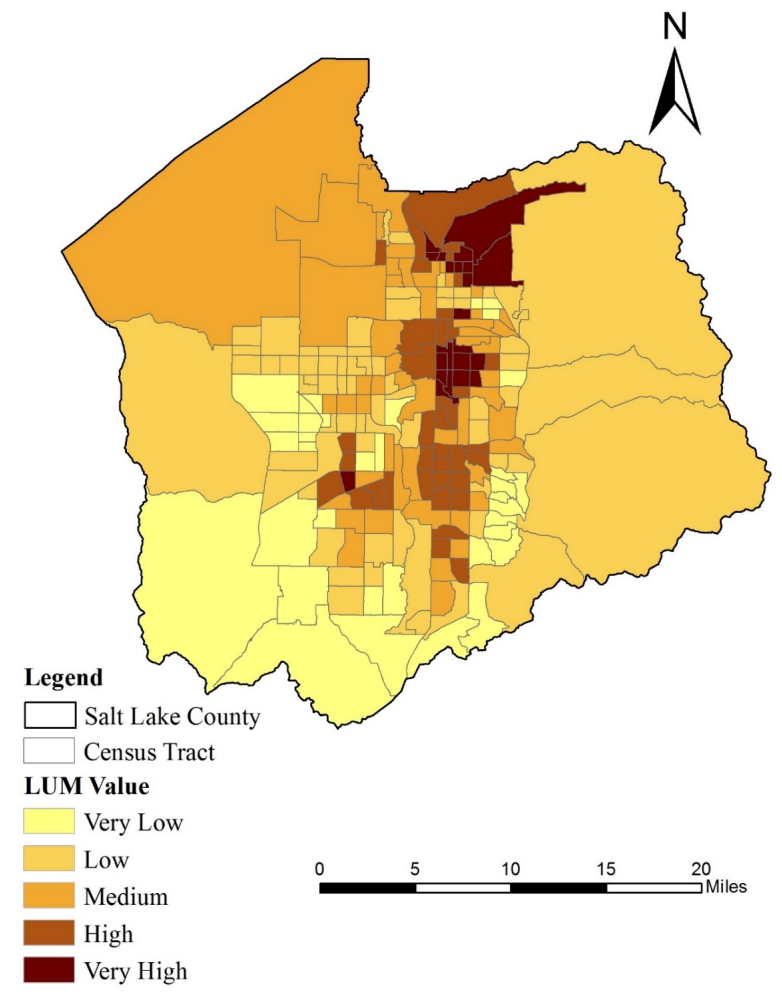

Figure 4. Spatial distribution of land use mix (LUM) in Salt Lake County.

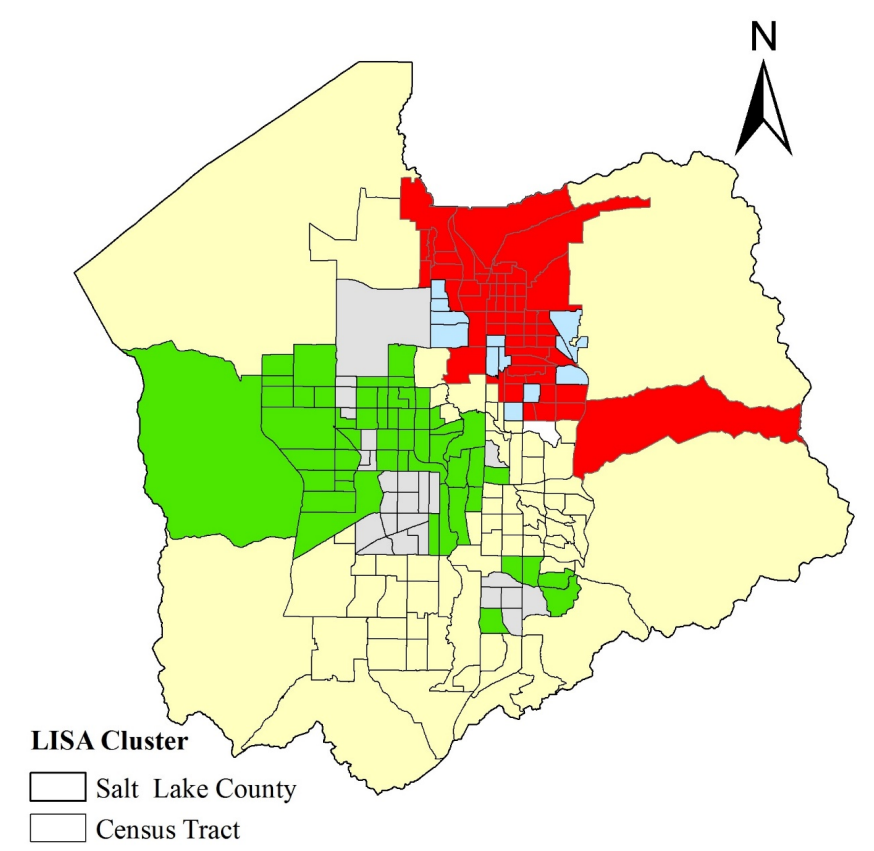

\section{Clusters}

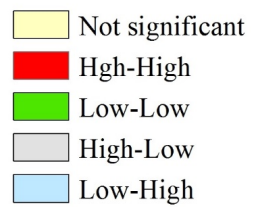

Figure 5. Spatial clusters of PA in Salt Lake County. 


\section{Result of Statistical and Spatial Analyses}

Based on the results of the performance of walkability index under different bandwidths, the neighborhood is defined as the 800-m road network buffer. The OLS linear regression model is used to examine the determinants of the PA in Salt Lake County and the results are shown in Table 2. The results of variance inflation factor (VIF) test for all the variables are all below 5 , indicating that there is no alarming multi-collinearity issue. The adjusted $R^{2}$ is 0.453 while the $\mathrm{p}$-value for F-statistics is significant, suggesting the great fitness of this regression model.

Table 2. Ordinary least squares (OLS) regression results.

\begin{tabular}{ccc}
\hline Variable & Coefficient & $p$-Value \\
\hline & Accessibility & \\
\hline Distance to bus stop & -0.037 & 0.670 \\
Distance to light rail stop & -0.061 & 0.685 \\
\hline \multicolumn{3}{c}{ Amenity } \\
\hline Distance to park & -0.152 & 0.191 \\
Distance to worship & 0.232 & 0.04 \\
\hline & Socio-demographic Conditions & \\
\hline Average AGE & 0.005 & 0.067 \\
Average education level & 0.735 & 0.0003 \\
Vehicles per person & -0.146 & 0.181 \\
Percentage of adult worker & 0.232 & 0.152 \\
Household income & -0.037 & 0.116 \\
\hline & Land use & \\
\hline Dwelling density & 1381 & 0.021 \\
Street connectivity & -3198 & 0.187 \\
Land use mix & -0.127 & 0.316 \\
Retail floor area & 12.98 & 0.027 \\
\hline & Assessment & \\
\hline$R^{2}$ & & 0.4452 \\
\hline
\end{tabular}

According to Figure 3, land use factors can explain about $15 \%$ of the variance of the dependent variables, so the land use indicators play a vital role in explaining people's walking behavior. Among these four factors, dwelling density and retail floor area ratio show great significance and both contribute positively to PA. Higher population density indicates more walkable communities. The commercial land use is also a key element in promoting walkability and thus the compact design of the commercial land use could help to improve neighborhood walkability.

Figure 6 shows the spatial distribution of the dwelling density and retail floor area ratio. There are many similarities of the spatial distributions of these two variables in Salt Lake County. High dwelling density regions concentrate around the downtown and university areas while these regions also possess high retail floor area ratio.

In addition, the socio-demographic factors are significant in the OLS regression model. Age and education level are important determinants of walkability. Age has a positive effect on walkability, and the young families tend to walk less than comparatively older families. Education level is the most significant determinant in this model, as well-educated family walk more. This confirms the importance of education in promoting walkability [75].

To account for the spatial autocorrelation of PA in Salt Lake County, the spatial lag model is implemented and the results are presented in Table 3. Comparing these two models, the $R^{2}$ is improved from 0.45 to 0.46 , which is not a significant improvement. However, the spatial lag variable is significant. 


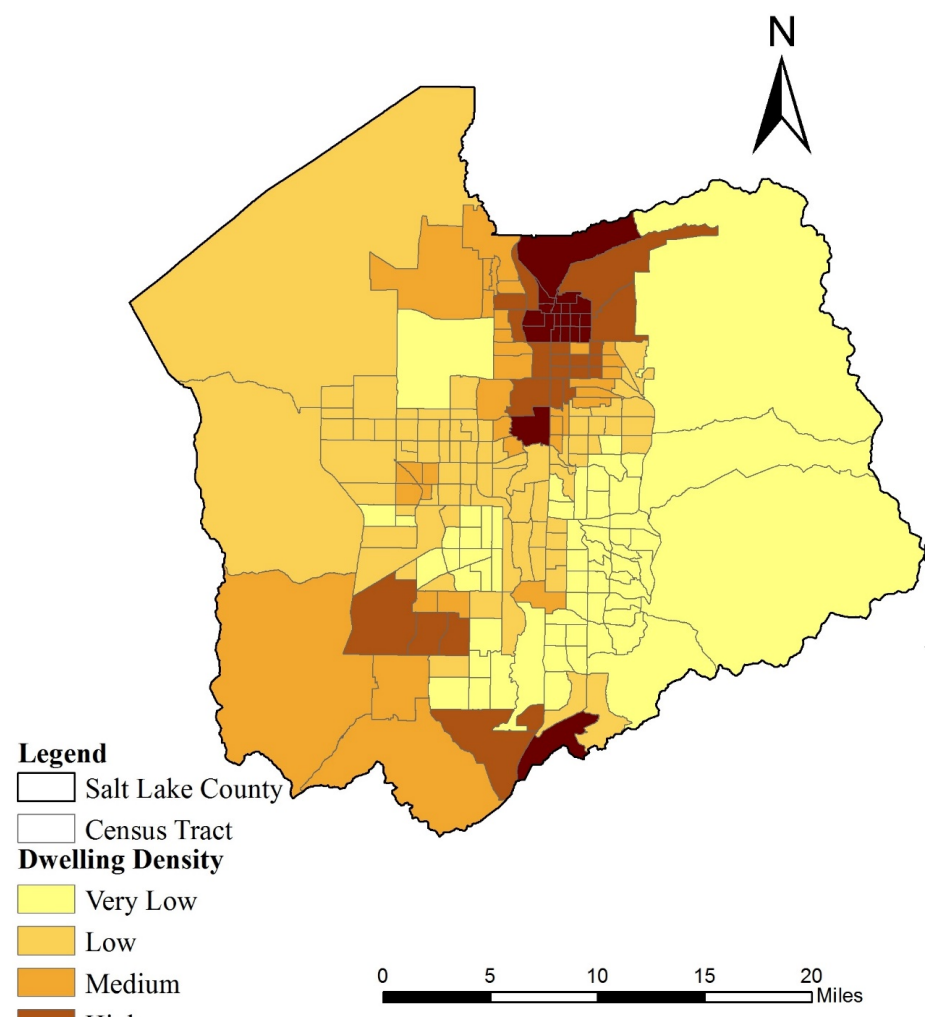

(a)

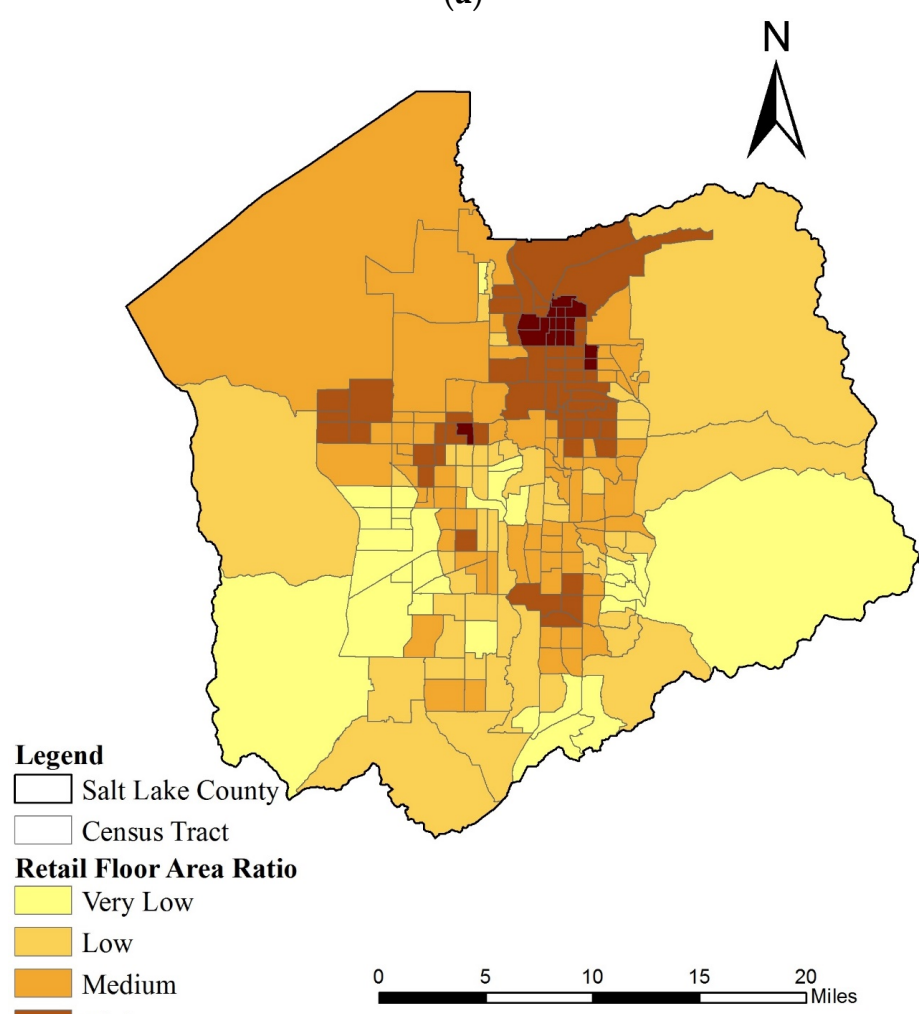

(b)

Figure 6. (a) Spatial distribution of dwelling density in Salt Lake County. (b) Spatial distribution of retail floor area ratio in Salt Lake County. 
Table 3. Spatial lag regression result.

\begin{tabular}{|c|c|c|}
\hline \multirow{2}{*}{ Variable } & \multicolumn{2}{|c|}{ Coefficient } \\
\hline & OLS Linear Regression Model & Regression Model with Spatial Lag \\
\hline \multicolumn{3}{|c|}{ Accessibility } \\
\hline Distance to bus stop & -0.037 & -0.013 \\
\hline Distance to light rail stop & -0.061 & -0.011 \\
\hline \multicolumn{3}{|c|}{ Amenity } \\
\hline Distance to park & -0.152 & -0.129 \\
\hline Distance to worship & $0.232 *$ & $0.221 *$ \\
\hline \multicolumn{3}{|c|}{ Social economic status } \\
\hline Average AGE & $0.005 *$ & $0.006^{*}$ \\
\hline Average education level & $0.735^{* * *}$ & $0.717^{* * *}$ \\
\hline Vehicles per person & -0.146 & 0.143 \\
\hline Percentage of adult worker & 0.232 & 0.174 \\
\hline Household income & -0.037 & -0.036 \\
\hline \multicolumn{3}{|c|}{ Land use } \\
\hline Dwelling density & $1381 *$ & 1134 * \\
\hline Street connectivity & -3196 & -2346 \\
\hline Land use mix & -0.127 & -0.093 \\
\hline Retail floor area & 12.98 * & 12.3 * \\
\hline Rho & / & $0.0022 *$ \\
\hline \multicolumn{3}{|c|}{ Assessment } \\
\hline$R^{2}$ & 0.4452 & 0.4593 \\
\hline
\end{tabular}

\section{Discussion}

As we have discussed in the literature review, little work has been done to examine the impacts of geographical scales when testing the PA-walkability link. The 800 -m road network buffer is usually considered to be the best choice to define the neighborhood [11,57]. However, the underlying reasons for the selection of this bandwidth is less discussed. This paper tests the performance of the four land use indicators, confirms the validity of the $800-\mathrm{m}$ bandwidth, and finds the threshold for defining neighborhood (1600-m network buffer). On average, it is estimated that the $800-\mathrm{m}$ walk takes $10 \mathrm{~min}$ and the 1600-m walk takes $20 \mathrm{~min}$. However, 30-min moderate-vigorous PA on at least five days each week is recommended for adults [23,34] and $60 \mathrm{~min}$ for the youth [76]. Hence, most of the current neighborhood designs are unlikely to be sufficiently facilitate neighborhood residents to meet the PA recommendation.

This study employs the four-component walkability index as the land use indicators to explore people's walking minutes in Salt Lake County. With the 800-m network buffer defined as the neighborhood, the walkability index can explain about $15 \%$ variance of PA without any other control variables. The walkability index's contribution to the variance of PA is larger than what is reported in the research conducted in Atlanta and King County, Washington, wherein it respectively explains $10.7 \%$ and $8.3 \%$ variance of PA [11,12]. Hence, people's walking behavior relies on neighborhood land use more significantly in Salt Lake County. Since the neighborhood land use cannot meet the general requirement of at least $30 \mathrm{~min}$ moderate-vigorous PA, improving the density of the neighborhood land use will play an important role in promoting walkability in the future.

As the urban sprawl phenomenon is looming large in the United States, increasing population density and land use diversity is recommended to policy makers because the compact city with medium-high density housing can facilitate the sustainability of the city [77]. Numerous studies have 
documented that increasing the density can decrease vehicle mile of travel (VMT) and create short trips $[12,47,52]$. The created short trips will make people walk more in the neighborhoods. In the northeastern area of Salt Lake County, the density is relatively high. But in other areas, the density is low. The government and policy makers should pay more attention to increasing the density in these areas.

Among the four traditional variables in walkability index, the land use mix is not significant at various geographical scales. One reason is that the relationship between land use mix and PA depends on the study area and trip type. After checking the destinations of the 490 trips taken by the 158 households, we find that over 200 trips are for exercising or walking with the dog. These trips are less likely to be affected by the mix-used land and are more likely to be influenced by neighborhood land use, personal preference and social demographic status. Another reason might be that Salt Lake County is at low mix land use level. The 2800 households covering the entire Salt Lake County are considered to calculate the four-category land use mix. The average value of land use mix in Salt Lake County is 0.22 , while the land use mix values are 0.31 in King County and 0.38 in Atlanta [11,12]. Compared to these two well-developed regions, the mix use is relatively low in Salt Lake County.

Previous studies on the relationship between walkability and neighborhood environment rarely consider spatial autocorrelation. However, based on the result of Moran's I test, spatial autocorrelation should not be ignored. If we ignore the spatially lagged term, the coefficients in the regression model would be biased [78]. In this research, both OLS and spatial lag regression models are implemented and the regression results affirm that spatial lag regression model is a good method in this research. However, spatial lag regression model only considers the spatial autocorrelation in dependent variables (lagged dependent variable). Other spatial regression models should be employed in further studies.

\section{Conclusions}

As the obesity epidemic becomes a serious problem in the United States, physical inactivity, a risk factor of obesity, has drawn much attention. Promoting PA is good for sustainable development and people's health. Walking is a sustainable transport mode that is available to people without any impending costs, and can significantly increase the physical fitness of people. In recent years, several studies are being undertaken to examine the determinants of people's PA.

In this paper, PA is predicted by land use and walkability index, accessibility to transportation, and socio-demographic status. The walkability indices at various geographic scales are constructed and tested, suggesting that the spatial threshold for defining neighborhood for the purpose of examining PA is $1600 \mathrm{~m}$. In addition, the dwelling density, street connectivity, and retail floor area ratio are significant determinants for PA while the land use mix is not. We also find that the best bandwidth for defining neighborhood is $800 \mathrm{~m}$. An OLS linear regression model and a spatial lag model are employed to examine the relationship between neighborhood land-use, socio-demographic status, and PA. The results show that land use and socio-demographic status are the dominating determinants of PA. Density and compact design for land use are key elements in promoting PA and therefore efforts are still needed to improve density and compact design.

These findings should help researchers, policy makers and practitioners gain a better understanding of the determinants of PA so that effective interventions and programs can be implemented to achieve the sustainable development of cities. In a contrast to sprawling urban pattern, compact urban form and design can significantly improve neighborhood walkability and promote people's preference for walking. In future work, more urban evolution factors should be examined such as urban land expansion, which also influences PA and sustainability [79].

Acknowledgments: We would like to acknowledge the funding of the CSBS Interdisciplinary Research Pilot Program at the University of Utah and the National Natural Science Foundation of China (41329001). This research was also partly supported by the National Institute of General Medical Sciences of the National Institutes of Health under award number R01CA140319-01A1 issued to Ming Wen. 
Author Contributions: Yehua Dennis Wei and Weiye Xiao contributed to research design and data analysis. Yehua Dennis Wei, Weiye Xiao, Ming Wen and Ran Wei wrote the paper. All authors have read and approved the final manuscript.

Conflicts of Interest: The authors declare no conflict of interest.

\section{References}

1. Ogden, C.L. Prevalence of obesity in the United States, (2009-2010). NCHS Data Brief 2012, 82, 1-8. [PubMed]

2. Salt Lake County Health Department. Obesity Prevention. Available online: http://slco.org/slcohealth/ programs/beActiveAndHealthy/obesity.html (accessed on 6 September 2015).

3. Katzmarzyk, P.T.; Gledhill, N.; Shephard, R.J. The economic burden of physical inactivity in Canada. Can. Med. Assoc. J. 2000, 163, 1435-1440.

4. Crespo, C.J.; Smit, E.; Andersen, R.E.; Carter-Pokras, O.; Ainsworth, B.E. Race/ethnicity, social class and their relation to physical inactivity during leisure time: Results from the Third National Health and Nutrition Examination Survey, 1988-1994. Am. J. Prev. Med. 2000, 18, 46-53. [CrossRef]

5. Bauman, A.E.; Reis, R.S.; Sallis, J.F.; Wells, J.C.; Loos, R.J.; Martin, B.W.; Lancet Physical Activity Series Working Group. Correlates of physical activity: Why are some people physically active and others not? Lancet 2012, 380, 258-271. [CrossRef]

6. Saelens, B.E.; Sallis, J.F.; Black, J.B.; Chen, D. Neighborhood-based differences in physical activity: An environment scale evaluation. Am. J. Public Health 2003, 93, 1552-1558. [CrossRef] [PubMed]

7. Frank, L.D.; Engelke, P.O. The built environment and human activity patterns: Exploring the impacts of urban form on public health. J. Plan. Lit. 2001, 16, 202-218. [CrossRef]

8. Brown, B.B.; Yamada, I.; Smith, K.R.; Zick, C.D.; Kowaleski-Jones, L.; Fan, J.X. Mixed land use and walkability: Variations in land use measures and relationships with BMI, overweight, and obesity. Health Place 2009, 15, 1130-1141. [CrossRef] [PubMed]

9. Brown, B.B.; Smith, K.R.; Hanson, H.; Fan, J.X.; Kowaleski-Jones, L.; Zick, C.D. Neighborhood design for walking and biking: Physical activity and body mass index. Am. J. Prev. Med. 2013, 44, 231-238. [CrossRef] [PubMed]

10. Christian, H.E.; Fiona, C.B.; Nicholas, J.M.; Matthew, W.K.; Mark, L.D.; Paula, H.; Anura, A.; Giles-Corti, B. How important is the land use mix measure in understanding walking behavior? Results from the RESIDE study. Int. J. Behav. Nutr. Phys. Act. 2011. [CrossRef] [PubMed]

11. Frank, L.D.; Schmid, T.L.; Sallis, J.F.; Chapman, J.; Saelens, B.E. Linking objectively measured physical activity with objectively measured urban form. Am. J. Prev. Med. 2005, 28, 117-125. [CrossRef] [PubMed]

12. Frank, L.D.; Sallis, J.F.; Conway, T.L.; Chapman, J.E.; Saelens, B.E.; Bachman, W. Many pathways from land use to health: Associations between neighborhood walkability and active transportation, body mass index, and air quality. J. Am. Plan. Assoc. 2006, 72, 75-87. [CrossRef]

13. Lee, R.E.; Booth, K.M.; Reese-Smith, J.Y.; Regan, G.; Howard, H.H. The Physical Activity Resource Assessment (PARA) instrument: Evaluating features, amenities and incivilities of physical activity resources in urban neighborhoods. Int. J. Behav. Nutr. Phys. Act. 2005. [CrossRef] [PubMed]

14. Caspersen, C.J.; Powell, K.E.; Christenson, G.M. Physical activity, exercise, and physical fitness: Definitions and distinctions for health-related research. Public Health Rep. 1985, 100, 126-130. [PubMed]

15. Pate, R.R.; Pratt, M.; Blair, S.N.; Haskell, W.L.; Macera, C.A.; Bouchard, C.; Buchner, D.; Ettinger, W.; Heath, G.W.; King, A.C. Physical activity and public health: A recommendation from the Centers for Disease Control and Prevention and the American College of Sports Medicine. J. Am. Med. Assoc. 1995, 273, 402-407. [CrossRef]

16. Andersen, R.E.; Crespo, C.J.; Bartlett, S.J.; Cheskin, L.J.; Pratt, M. Relationship of physical activity and television watching with body weight and level of fatness among children: Results from the Third National Health and Nutrition Examination Survey. J. Med. Assoc. 1998, 279, 938-942. [CrossRef]

17. Fan, J.X.; Brown, B.B.; Hanson, H.; Kowaleski-Jones, L.; Smith, K.R.; Zick, C.D. Moderate to vigorous physical activity and weight outcomes: Does every minute count? Am. J. Health Promot. 2013, 28, 41-49. [CrossRef] [PubMed] 
18. Smith, K.R.; Brown, B.B.; Yamada, I.; Kowaleski-Jones, L.; Zick, C.D.; Fan, J.X. Walkability and body mass index: Density, design, and new diversity measures. Am. J. Prev. Med. 2008, 35, 237-244. [CrossRef] [PubMed]

19. Warburton, D.E.; Nicol, C.W.; Bredin, S.S. Health benefits of physical activity: The evidence. Can. Med. Assoc. J. 2006, 174, 801-809. [CrossRef] [PubMed]

20. Gordon-Larsen, P.; Nelson, M.C.; Page, P.; Popkin, B.M. Inequality in the built environment underlies key health disparities in physical activity and obesity. Pediatrics 2006, 117, 417-424. [CrossRef] [PubMed]

21. Powell, K.E.; Thompson, P.D.; Caspersen, C.J.; Kendrick, J.S. Physical activity and the incidence of coronary heart disease. Annu. Rev. Public Health 1987, 8, 253-287. [CrossRef] [PubMed]

22. Dunn, A.L.; Trivedi, M.H.; O'Neal, H.A. Physical activity dose-response effects on outcomes of depression and anxiety. Med. Sci. Sports Exerc. 2001, 33 (Suppl. 6), S587-S597. [CrossRef] [PubMed]

23. Haskell, W.L.; Lee, I.M.; Pate, R.R.; Powell, K.E.; Blair, S.N.; Franklin, B.A.; Macera, C.A.; Heath, G.W.; Thompson, P.D.; Bauman, A. Physical activity and public health: Updated recommendation for adults from the American College of Sports Medicine and the American Heart Association. Circulation 2007, 116, 1081-1093. [CrossRef] [PubMed]

24. Baecke, J.A.; Burema, J.; Frijters, J.E. A short questionnaire for the measurement of habitual physical activity in epidemiological studies. Am. J. Clin. Nutr. 1982, 36, 936-942. [PubMed]

25. Jacobs, D.R., Jr.; Ainsworth, B.E.; Hartman, T.J.; Leon, A.S. A simultaneous evaluation of 10 commonly used physical activity questionnaires. Med. Sci. Sports Exerc. 1993, 25, 81-91. [CrossRef] [PubMed]

26. Craig, C.L.; Marshall, A.L.; Sjöström, M.; Bauman, A.E.; Booth, M.L.; Ainsworth, B.E.; Pratt, M.; Ekelund, U.; Yngve, A.; Sallis, J.F.; et al. International physical activity questionnaire: 12-country reliability and validity. Med. Sci. Sports Exerc. 2003, 35, 1381-1395. [CrossRef] [PubMed]

27. Borowski, L.A.; Bowles, H.R. Resources for locating and selecting self-report measures of physical activity. J. Phys. Act. Health 2012, 9, S91-S92.

28. Ellery, C.V.L.; Weiler, H.A.; Hazell, T.J. Physical activity assessment tools for use in overweight and obese children. Int. J. Obes. 2014, 38, 1-10. [CrossRef] [PubMed]

29. Brown, B.B.; Wilson, L.; Tribby, C.P.; Werner, C.M.; Wolf, J.; Miller, H.J.; Smith, K.R. Adding maps (GPS) to accelerometry data to improve study participants' recall of physical activity: A methodological advance in physical activity research. Br. J. Sports Med. 2014, 48, 1054-1058. [CrossRef] [PubMed]

30. Hendelman, D.; Miller, K.; Baggett, C.; Debold, E.; Freedson, P. Validity of accelerometry for the assessment of moderate intensity physical activity in the field. Med. Sci. Sports Exerc. 2000, 32, S442-S449. [CrossRef] [PubMed]

31. Swartz, A.M.; Strath, S.J.; Bassett, D.R.; O’Brien, W.L.; King, G.A.; Ainsworth, B.E. Estimation of energy expenditure using CSA accelerometers at hip and wrist sites. Med. Sci. Sports Exerc. 2000, 32, S450-S456. [CrossRef] [PubMed]

32. Troiano, R.P.; Berrigan, D.; Dodd, K.W.; Masse, L.C.; Tilert, T.; McDowell, M. Physical activity in the United States measured by accelerometer. Med. Sci. Sports Exerc. 2008, 40, 181-188. [CrossRef] [PubMed]

33. Fan, J.X.; Kowaleski-Jones, L.; Wen, M. Walking or dancing patterns of physical activity by cross-sectional age among US women. J. Aging Health 2013, 25, 1182-1203. [CrossRef] [PubMed]

34. Hallal, P.C.; Andersen, L.B.; Bull, F.C.; Guthold, R.; Haskell, W.; Ekelund, U.; Lancet Physical Activity Series Working Group. Global physical activity levels: Surveillance progress, pitfalls, and prospects. Lancet 2012, 380, 247-257. [CrossRef]

35. Bradley, R.H.; McRitchie, S.; Houts, R.M.; Nader, P.; O’Brien, M. Parenting and the decline of physical activity from age 9 to 15. Int. J. Behav. Nutr. Phys. Act. 2011. [CrossRef] [PubMed]

36. Zick, C.D.; Smith, K.R.; Brown, B.B.; Fan, J.X.; Kowaleski-Jones, L. Physical activity during the transition from adolescence to adulthood. J. Phys. Act. Health 2007, 4, 125-137. [PubMed]

37. Wen, M.; Su, D. Correlates of Leisure-Time Physical Activity Participation Among Latino Children and Adolescents with Acanthosis Nigricans. J. Immigr. Minor. Health 2015, 17, 1330-1336. [CrossRef] [PubMed]

38. Bellocco, R.; Jia, C.; Ye, W.; Lagerros, Y.T. Effects of physical activity, body mass index, waist-to-hip ratio and waist circumference on total mortality risk in the Swedish National March Cohort. Eur. J. Epidemiol. 2010, 25, 777-788. [CrossRef] [PubMed]

39. Lee, P.H.; Macfarlane, D.J.; Lam, T.; Stewart, S.M. Validity of the international physical activity questionnaire short form (IPAQ-SF): A systematic. Int. J. Behav. Nutr. Phys. Act. 2011. [CrossRef] [PubMed] 
40. Löllgen, H.; Böckenhoff, A.; Knapp, G. Physical activity and all-cause mortality: An updated meta-analysis with different intensity categories. Int. J. Sports Med. 2009, 30, 213-224. [CrossRef] [PubMed]

41. Trost, S.G.; Pate, R.R.; Sallis, J.F.; Freedson, P.S.; Taylor, W.C.; Dowda, M.; Sirard, J. Age and gender differences in objectively measured physical activity in youth. Med. Sci. Sports Exerc. 2002, 34, 350-355. [CrossRef] [PubMed]

42. Quarmby, T.; Dagkas, S. Children's engagement in leisure time physical activity: Exploring family structure as a determinant. Leis. Stud. 2010, 29, 53-66. [CrossRef]

43. Marshall, S.J.; Jones, D.A.; Ainsworth, B.E.; Reis, J.P.; Levy, S.S.; Macera, C.A. Race/ethnicity, social class, and leisure-time physical inactivity. Med. Sci. Sports Exerc. 2007, 39, 44-51. [CrossRef] [PubMed]

44. Boarnet, M.; Crane, R. The influence of land use on travel behavior: Specification and estimation strategies. Transp. Res. Part A Policy Pract. 2001, 35, 823-845. [CrossRef]

45. Barton, H. Land use planning and health and well-being. Land Use Policy 2009, 26, S115-S123. [CrossRef]

46. Ewing, R.; Schmid, T.; Killingsworth, R.; Zlot, A.; Raudenbush, S. Relationship between urban sprawl and physical activity, obesity, and morbidity. Am. J. Health Promot. 2003, 18, 47-57. [CrossRef] [PubMed]

47. Ewing, R.; Cervero, R. Travel and the built environment: A synthesis. Transp. Res. Rec. J. Transp. Res. Board 2001, 1780, 87-114. [CrossRef]

48. Heath, G.W.; Brownson, R.C.; Kruger, J.; Miles, R.; Powell, K.E.; Ramsey, L.T.; Task Force on Community Preventive Services. The effectiveness of urban design and land use and transport policies and practices to increase physical activity: A systematic review. J. Phys. Act. Health 2006, 3, S55-S76.

49. Salvo, D.; Reis, R.S.; Stein, A.D.; Rivera, J.; Martorell, R.; Pratt, M. Peer Reviewed: Characteristics of the Built Environment in Relation to Objectively Measured Physical Activity Among Mexican Adults, 2011. Prev. Chronic Disease 2014, 11, 1-16.

50. Kaczynski, A.T.; Potwarka, L.R.; Saelens, B.E. Association of park size, distance, and features with physical activity in neighborhood parks. Am. J. Public Health 2008, 98, 1451-1456. [CrossRef] [PubMed]

51. McCormack, G.R.; Rock, M.; Toohey, A.M.; Hignell, D. Characteristics of urban parks associated with park use and physical activity: A review of qualitative research. Health Place 2010, 16, 712-726. [CrossRef] [PubMed]

52. Cervero, R.; Kockelman, K. Travel demand and the 3Ds: Density, diversity, and design. Transp. Res. Part D Transp. Environ. 1997, 2, 199-219. [CrossRef]

53. Ewing, R.; Cervero, R. Travel and the built environment: A meta-analysis. J. Am. Plan. Assoc. 2010, 76, 265-294. [CrossRef]

54. Humpel, N.; Owen, N.; Leslie, E. Environmental factors associated with adults' participation in physical activity: A review. Am. J. Prev. Med. 2002, 22, 188-199. [CrossRef]

55. Frank, L.D.; Sallis, J.F.; Saelens, B.E.; Leary, L.; Cain, K.; Conway, T.L.; Hess, P.M. The development of a walkability index: Application to the Neighborhood Quality of Life Study. Br. J. Sports Med. 2010, 44, 924-933. [CrossRef] [PubMed]

56. Leslie, E.; Coffee, N.; Frank, L.; Owen, N.; Bauman, A.; Hugo, G. Walkability of local communities: Using geographic information systems to objectively assess relevant environmental attributes. Health Place 2007, 13, 111-122. [CrossRef] [PubMed]

57. Manaugh, K.; El-Geneidy, A. Validating walkability indices: How do different households respond to the walkability of their neighborhood? Transp. Res. Part D Transp. Environ. 2011, 16, 309-315. [CrossRef]

58. Mayne, D.J.; Morgan, G.G.; Willmore, A.; Rose, N.; Jalaludin, B.; Bambrick, H.; Bauman, A. An objective index of walkability for research and planning in the Sydney Metropolitan Region of New South Wales, Australia: An ecological study. Int. J. Health Geogr. 2013. [CrossRef] [PubMed]

59. Van Dyck, D.; Deforche, B.; Cardon, G.; de Bourdeaudhuij, I. Neighbourhood walkability and its particular importance for adults with a preference for passive transport. Health Place 2009, 15, 496-504. [CrossRef] [PubMed]

60. Van Dyck, D.; Cardon, G.; Deforche, B.; Sallis, J.F.; Owen, N.; de Bourdeaudhuij, I. Neighborhood SES and walkability are related to physical activity behavior in Belgian adults. Prev. Med. 2010, 50, S74-S79. [CrossRef] [PubMed]

61. De Meester, F.; van Dyck, D.; de Bourdeaudhuij, I.; Deforche, B.; Sallis, J.F.; Cardon, G. Active living neighborhoods: Is neighborhood walkability a key element for Belgian adolescents? BMC Public Health 2012. [CrossRef] [PubMed] 
62. Sundquist, K.; Eriksson, U.; Kawakami, N.; Skog, L.; Ohlsson, H.; Arvidsson, D. Neighborhood walkability, physical activity, and walking behavior: The Swedish Neighborhood and Physical Activity (SNAP) study. Soc. Sci. Med. 2011, 72, 1266-1273. [CrossRef] [PubMed]

63. Yamada, I.; Brown, B.B.; Smith, K.R.; Zick, C.D.; Kowaleski-Jones, L.; Fan, J.X. Mixed land use and obesity: An empirical comparison of alternative land use measures and geographic scales. Prof. Geogr. 2012, 64, 157-177. [CrossRef] [PubMed]

64. Duncan, M.J.; Winkler, E.; Sugiyama, T.; Cerin, E.; Leslie, E.; Owen, N. Relationships of land use mix with walking for transport: Do land uses and geographical scale matter? J. Urban Health 2010, 87, 782-795. [CrossRef] [PubMed]

65. Tian, G.; Ewing, R.; Greene, W. Desire for Smart Growth: A Survey of Residential Preferences in the Salt Lake Region of Utah. Hous. Policy Debate 2015, 25, 446-462. [CrossRef]

66. Anselin, L. Spatial regression. In The SAGE Handbook of Spatial Analysis; Fotheringham, S., Rogerson, P., Eds.; SAGE: Los Angeles, CA, USA, 2009; pp. 255-276.

67. Lee, D.T.; Schachter, B.J. Two algorithms for constructing a Delaunay triangulation. Int. J. Comput. Inf. Sci. 1980, 9, 219-242. [CrossRef]

68. Pace, R.K.; LeSage, J.P. Chebyshev approximation of log-determinants of spatial weight matrices. Comput. Stat. Data Anal. 2004, 45, 179-196. [CrossRef]

69. Yu, D.; Wei, Y.H.D.; Wu, C. Modeling spatial dimensions of housing prices in Milwaukee, WI. Environ. Plan. B Plan. Des. 2007, 34, 1085-1102. [CrossRef]

70. Root, E.D. Moving neighborhoods and health research forward: Using geographic methods to examine the role of spatial scale in neighborhood effects on health. Ann. Assoc. Am. Geogr. 2012, 102, 986-995. [CrossRef] [PubMed]

71. Sallis, J.; Owen, N. Physical Activity and Behavioral Medicine; Sage Publications: Thousand Oaks, CA, USA, 1999.

72. Spence, J.C.; Lee, R.E. Toward a comprehensive model of physical activity. Psychol. Sport Exerc. 2003, 4, 7-24. [CrossRef]

73. Moudon, A.V.; Lee, C.; Cheadle, A.D.; Garvin, C.; Johnson, D.; Schmid, T.L.; Weathers, R.D.; Lin, L. Operational definitions of walkable neighborhood: Theoretical and empirical insights. J. Phys. Act. Health 2006, 3, S99-S117.

74. Schlossberg, M.; Brown, N. Comparing transit-oriented development sites by walkability indicators. Transp. Res. Rec. J. Transp. Res. Board 2004, 1887, 34-42. [CrossRef]

75. Heath, G.W.; Parra, D.C.; Sarmiento, O.L.; Andersen, L.B.; Owen, N.; Goenka, S.; Montes, F.; Brownson, R.C.; Lancet Physical Activity Series Working Group. Evidence-based intervention in physical activity: Lessons from around the world. Lancet 2012, 380, 272-281. [CrossRef]

76. Strong, W.B.; Malina, R.M.; Blimkie, C.J.; Daniels, S.R.; Dishman, R.K.; Gutin, B.; Hergenroeder, A.C.; Must, A.; Nixon, P.A.; Pivarnik, J.M. Evidence based physical activity for school-age youth. J. Pediatr. 2005, 146, 732-737. [CrossRef] [PubMed]

77. Ancell, S.; Thompson-Fawcett, M. The social sustainability of medium density housing: A conceptual model and Christchurch case study. Hous. Stud. 2008, 23, 423-442. [CrossRef]

78. Anselin, L. Spatial Econometrics: Methods and Models; Kluwer: Dordrecht, The Netherlands, 1988.

79. Gao, J.; Wei, Y.H.D.; Chen, W.; Yenneti, K. Urban Land Expansion and Structural Change in the Yangtze River Delta, China. Sustainability 2015, 7, 10281-10307. [CrossRef]

(C) 2016 by the authors; licensee MDPI, Basel, Switzerland. This article is an open access article distributed under the terms and conditions of the Creative Commons by Attribution (CC-BY) license (http://creativecommons.org/licenses/by/4.0/). 